\title{
Second-Generation Synthesis of (-)-Viriditoxin
}

\author{
Charles I. Grove and Jared T. Shaw \\ Department of Chemistry, University of California, One Shields Ave, Davis, CA 95616
}

Jared T. Shaw: jtshaw@ucdavis.edu

\section{Abstract}

Viriditoxin is a secondary metabolite isolated from Aspergillus viridinutans that has been shown to inhibit FtsZ, the bacterial homologue of eukaryotic tubulin. A streamlined, scalable, and highly diastereoselective synthesis of this complex natural product is described. Key advances include a more efficient synthesis of the requisite unsaturated pyranone, scalable assembly of the naphthopyranone monomer, and improved diastereoselectivity in the biaryl-coupling reaction. In addition, we disclose a serendipitous ruthenium-catalyzed anion dimerization resulting from trace metal left by an RCM reaction.

\section{Keywords}

natural products; stereoselective synthesis; antibiotics; atropisomerism; biaryls

\section{Introduction}

The synthesis of natural products as a starting point for achieving a better understanding of their ability to modulate biological processes is an important goal for the discovery of new medicines. Among current health challenges, the ability of pathogenic bacteria to evade the activity of current antibiotics has prompted a need for new chemotypes and new protein targets in prokaryotes. Although there has been some progress in finding new drugs to inactivate established targets, there is a parallel effort to find new targets that are susceptible to modulation by small molecules. Bacterial cell division is modulated by a group of proteins for which inhibitors could represent starting points for drug discovery. [1] The central cell division protein, FtsZ, is a homologue of eukaryotic tubulin that plays a similarly critical role in the cytokinesis of bacterial cells. [2] This protein was first characterized in 1992 as a tubulin-like GTPase [3] and in the ensuing decades, several inhibitors have been discovered from natural and synthetic sources. [3d] Our group has developed a research program around the synthesis and study of natural products that inhibit bacterial cell division by targeting FtsZ with the long term goal of elucidating the molecular basis of inhibition.

Viriditoxin is a polyketide natural product first isolated at the Northern Regional Research Laboratory (NRRL, Peoria, IL, USA) [4] [5] and subsequently discovered to inhibit the function of FtsZ by researchers at Merck conducting a high-throughput screen of natural product extracts. [6] This compound inhibited the GTPase activity of FtsZ in vitro and also exhibited broad activity against Gram-positive bacteria. Importantly, it is not cytotoxic to either yeast or human cells, suggesting that it has some level of target specificity. We initiated a project to synthesize viriditoxin so that we could study its interactions with FtsZ in detail and eventually identify the molecular interactions between this compound and FtsZ.

(C) Thieme Stuttgart

Correspondence to: Jared T. Shaw, jt shaw@ucdavis . edu. 
Although the mammalian toxicity of this compound limits the extent to which it might be a starting point for drug discovery, [7] detailed structural knowledge of how viriditoxin interacts with FtsZ would serve as a starting point for exploiting this protein as a target for new antibiotics.

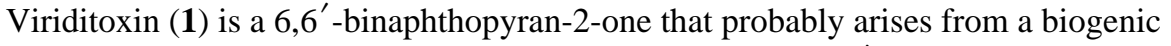
oxidative dimerization (Figure 1). The few known related 6,6'-binaphthopyran-2-ones include the isomeric diacid asteromine (2) [8] as well as the methyl and propyl analogues pigmentosin A (3) [9] and talaroderxine A (4). [10] All have the same relative stereochemical relationship between the axial chirality of the biaryl linkage and the substituent of the pyranone ring. The lone exception to this trend is talaroderxine B (not shown), which is the axial isomer of talaroderxine A and is isolated from the same organism. In addition to the 6,6'-binaphthopyran-2-ones, related natural products arising from the dimerization of condensed polyketides include $8,8^{\prime}$-binaphthopyran-2-ones (e.g. 6 , vioxanthin [11]) and 6,6'-binaphthopyran-4-ones such as cephalochromin (5). [12] Given the ease with which polyhydroxylated aromatic rings can undergo oxidative dimerization, many related dimeric and oligomeric natural products have been isolated, usually from fungi. [13]

At the outset of our studies, there had been no previous syntheses of $6,6^{\prime}$ binaphthopyranones. The assembly of axially chiral natural products has been a longstanding challenge in organic synthesis for which many elegant approaches have been developed. [14] Although the focus of many synthetic efforts centers on the construction of the stereoselective construction of biaryl linkage, the efficient preparation of the dimerization precursors is of equal importance to the overall synthetic efficiency. We recently completed a stereoselective synthesis of (-)-viriditoxin that confirmed its configuration and demonstrated the efficacy of vanadium-catalyzed phenolic coupling for enhancing or reversing remote diastereoselection in this reaction. [15] Although this synthesis answered many important questions and has enabled subsequent biological investigations, we have explored several strategies for improving efficiency and scalability. Herein we describe studies that culminated in a 'second-generation' synthesis of (-)viriditoxin with significant improvements to the substrate preparation, manipulation of protecting groups, and selectivity in the biaryl-coupling reaction

\section{Retrosynthetic Analysis of Viriditoxin}

Two basic strategies were considered for constructing the biaryl core of viriditoxin. One approach is to use simplified phenyl precursors in an early state biaryl coupling and then construct the polycyclic systems in a bi-directional synthesis. This pathway was used to prepare vioxanthin [16] and, more recently, to assemble a simplified model system representing the core of hibarimicin. [17] In both cases, key steps involving condensation reactions to build polycyclic ring systems were modest-yielding. A second approach would involve construction of the condensed polycyclic monomers followed by late-stage biaryl coupling. This strategy has been successful in the syntheses of perylenequinone natural products [18] and nigerone, [19] which employ oxidative coupling of organometallic intermediates and phenols, respectively. We favored the latter strategy from the outset with the hope that installation of the axial chirality could be executed efficiently and with high diastereoselectivity. We first investigated dimerization of organometallic intermediates using both catalytic cross-coupling or oxidative homocoupling reactions with limited success. The advantage for this approach stems from installing a methyl group for $\mathrm{P}^{2}$ which is part of the final target structure. In the end, a phenolic coupling was successful, necessitating a protecting group $\left(\mathrm{P}^{2}\right)$ that was orthogonal to two additional phenolic protecting groups $\left(\mathrm{P}^{3}\right.$ and $\left.\mathrm{P}^{4}\right)$ as well as the protecting group on the primary alcohol $\left(\mathrm{P}^{1}\right)$. 
Assembly of the tricyclic precursor $\mathbf{7}$ is achieved through a condensation reaction between a protected orsellinate ester $\mathbf{8}$ and a suitable unsaturated carbonyl compound $\mathbf{9}$ [Scheme 1] (A)]. The condensation reaction itself can be executed in either a one-step (StauntonWeinreb) transformation or Michael-Dieckmann reaction followed by oxidation to the corresponding naphthol. Both manifolds were investigated and ultimately the latter proved to be more efficient. The Michael-Dieckmann pathway necessitated an efficient synthesis of pyranone $\mathbf{9}$, which was initially realized by an aldol addition and cyclization sequence [Scheme 1] (B)]. The requisite aldehyde was prepared with high enantioselectivity using an asymmetric allylation reaction employing allyltributyltin. Although this was adequate for our first-generation synthesis, we sought a route that would be more easily scaled and require fewer air-sensitive steps. As a result, we turned to ring-closing metathesis (RCM) for pyranone formation and replaced the allylation reaction with the opening of an epoxide derived from 1 -aspartic acid. This feature article details our development of a secondgeneration synthesis of (-)-viriditoxin in which nearly every step has been replaced and improved with respect to scalability and yield.

\section{Synthesis of the Pyranone Substrate for the Michael-Dieckmann Reaction}

One major goal for the second-generation synthesis of viriditoxin was to replace the use of allyltributyltin at the beginning of the synthesis [Scheme 2] (A)]. Although the allylation of aldehyde $\mathbf{1 4}$ proceeded with excellent enantioselectivity and acceptable yield, the toxicity of the allyltin reagent made scaleup of this reaction undesirable. An attractive alternative involved the opening of epoxide $\mathbf{1 5}$ in which the primary alcohol is protected with either a triisopropylsilyl (TIPS) or tert-butyldiphenylsilyl (TBDPS) group [Scheme 2] (B)]. The reason for the change from TIPS, which was adequate for the first-generation synthesis, to TBDPS is described later (vide infra). Based on the work of Volkmann, [20] aspartic acid was converted into the diazonium salt and displaced with bromide in a stereospecific process with double inversion. This reaction was easily conducted on large (79 g) scale. The resultant diacid was then reduced to diol $\mathbf{1 6}$ and subsequently, in one pot, treated with base to form the epoxide and alkoxide anion that was trapped with a silyl chloride. Epoxides 15a [21] and 15b [22] were treated with vinylmagnesium chloride to form the homoallylic alcohols 13a and 13b that were then acylated with acryloyl chloride to 12a [23] and 12b, [24] respectively. Ring closing metathesis of dienes 12a and 12b with second-generation Grubbs catalyst proceeded smoothly to give pyranones $9 \mathbf{a}$ and $\mathbf{9 b}$ in high yields. In early studies, using progenitors to the $\mathrm{G} 2$ catalyst, we had attempted a similar ring closure and observed little or no conversion, which led us to initially avoid this route. In summary, pyranones $9 \mathbf{a}$ and $9 \mathbf{b}$ were made in a comparable number of transformations with improved overall yield of $26 \%$ and $49 \%$, respectively. Importantly, this route can be safely and easily executed on multigram scale.

\section{Napthopyranone Assembly}

We initially explored the one-step Staunton-Weinreb condensation [25] and observed unacceptably low yields. Concurrent with our studies, a synthesis of semi-viriditoxin was published using this approach with an optimized yield of 36\%, [26] consistent with our findings. The two-step Michael-Dieckmann/oxidation approach to prepare the same intermediate 20a [15] proceeds in 82\% yield from 9a (Scheme 3C). Although the analogous reaction to produce $20 \mathrm{~b}$ from $\mathbf{9 b}$ eventually worked in acceptable yield on large scale (53\%), the success of this step was dependent on the source of the pyranone starting material.

We encountered an unforeseen difficulty in the Michael-Dieckmann reaction of pyranones produced using the RCM route [Scheme 3 (B)]. While using this method to prepare substrates for a study of catalyst scope, we examined the condensation reaction of pyranone 
$\mathbf{1 7}$, which is derived from $(R)$-glycidol. Treatment of $\mathbf{1 7}$ with the anion derived from orsellinate 8 resulted in little or no product formation [Scheme 3 (A)]. It was noticed that, after column chromatography, batches of $\mathbf{1 7}$ had a slightly brown tinge to them, suggestive of trace ruthenium byproducts carried over from the RCM step. Although it seemed implausible that trace quantities of any impurity would interfere significantly with the reaction of stoichiometric quantities of an anion, methods for removing trace metals were investigated. Thorough pre-treatment with activated charcoal resulted in $44 \%$ yield in the annulation reaction and washing with a methanolic solution of tris(hydroxymethyl)phosphine [27] completely restored the yield we had seen previously. In the failed reaction mixtures, complete consumption of the starting materials was observed and, after careful chromatography, orsellinate dimer 19 was isolated [Scheme 3(B)]. The structure of 19 was deduced based on ${ }^{1} \mathrm{H}$ and ${ }^{13} \mathrm{C}$ NMR spectroscopy and confirmed by $\mathrm{X}$ ray crystallography. [28] Control experiments revealed that pure pyranone 17 could be spiked with Grubbs catalyst to divert the reaction toward production of 19. Furthermore, 19 is not formed when pyranone $\mathbf{1 7}$ is excluded, even in the presence of ambient oxygen. We are not inclined to speculate on the exact catalytic mechanism of this reaction, but all available data suggest that this homodimerization is catalyzed by ruthenium and that pyranone $\mathbf{1 7}$ is the terminal oxidant that enables catalyst turnover. Although similar reactivity has been observed in related anion dimerizations, this is one of the few examples involving metal catalysis and a mild oxidant.

\section{Biaryl Bond Construction and Completion of Viriditoxin}

Early studies in our laboratory focused on possible cross- or homo-coupling reactions. To this end, we employed model system $\mathbf{2 1}$, which is derived from commercially available $2 \mathrm{H}$ pyran-2-one. This naphthopyranone underwent regioselective iodination when treated with $N$-iodosuccinimide in acetonitrile (Scheme 4). Attempts to use this substrate for magnesiumhalogen exchange were thwarted by the unexpected displacement of the methoxy group next to the carbonyl of the pyranone ring. In fact, only the product of displacement $\mathbf{2 4}$ and displacement and exchange $\mathbf{2 5}$ were observed, i.e. no products derived from the quenching of the expected organomagnesium halide intermediate $\mathbf{2 3}$ were isolated. This result demonstrates that the displacement occurs at a rate similar to that of exchange. We recently published an account of our observations on the scope of this reaction. [29] Use of a 4toluene-sulfonyl protecting group in place of the methyl allowed us to more fully explore exchange reactions. Unfortunately, little or no product was observed when we attempted to prepare aryltin or arylboronates to be employed in Stille or Suzuki reactions, respectively. Moreover, attempts to prepare arylithium or arylmagnesium halide intermediates to be used in oxidative homocoupling reactions proceeded in low yields.

We next turned our attention to the use of phenolic coupling reactions. This route would necessitate a protecting group on the orsellinate fragment $\left(\mathrm{P}^{2}\right)$ that was orthogonal to the other three hydroxy protecting groups. We initially explored the use of benzyl or 4methoxybenzyl, but found that the Michael-Dieckmann process was low-yielding (not shown). Ultimately use of the ethoxymethyl (EOM) group proved suitable for the MichaelDieckmann reaction and this group could, in theory, be cleaved in the presence of the TIPS group $\left(\mathrm{P}^{1}\right)$. Use of various acidic conditions were always accompanied by TIPS cleavage. Thermal conditions reported by Miyake proved useful for cleaving the EOM group under neutral conditions. [30] On some runs, yields of 29a as high as 70\% were observed (Scheme 5). Unfortunately, slight variations in the temperature or the reaction time were deleterious to this reaction and resulted in either recovery or complete decomposition of the starting material. Although we used this method successfully for the first-generation synthesis, we sought an alternative that would be more reliable. TBDPS ethers of primary alcohols have similar steric demand when compared to TIPS and significantly higher acid stability. Given 
the ease with which phenolic MOM or EOM ethers can be cleaved, we felt that the TBDPS might be sufficiently more stable so as to permit acid hydrolysis. Exposure of $\mathbf{7 b}$ to zinc bromide and propanethiol [31] resulted in rapid EOM removal to produce 29b with no appreciable silyl group cleavage. This reaction could be scaled up easily and showed little run-to-run variation in efficiency.

The vanadium-catalyzed coupling of $\mathbf{2 9 b}$ exhibited significant differences when compared to the TIPS analogue. In our initial exploration of this reaction using Gong-type [32] catalysts derived from ( $S$ )-BINOL and $L$-valine 31a, TIPS-protected 29a underwent phenolic coupling with 89:11 dr. This same catalyst converted 29b into biaryl intermediate 30 in 65\% yield and $>95: 5$ diastereoselectivity [Scheme 6(A)]. Examination of two new catalyst structures $\mathbf{3 1 b}, \mathbf{c}$ derived from tert-leucine and isoleucine, respectively, proceeded in $85 \%$ and $80 \%$ yields with similarly high diastereoselectivity. Finally, Treatment of $\mathbf{3 0}$ with potassium carbonate and dimethyl sulfate followed by tetrabutylammonium fluoride furnished 33, which intercepted the first-generation synthetic route [Scheme 6(B)]. This intermediate was carried on to (-)-viriditoxin in four steps in an optimized overall yield of $42 \%$, which was a noticeable improvement from our original report.

Synthetic (-)-viriditoxin is identical to naturally derived material in all respects. At the time of our first synthesis, we observed ${ }^{1} \mathrm{H}$ and ${ }^{13} \mathrm{C}$ NMR spectra that compared favorably with reported values. In addition, Dr. Sheo Singh, who conducted the isolation at Merck, provided us with a copy of the original ${ }^{1} \mathrm{H}$ NMR spectrum that he recorded. The only discrepancy was in our observed optical rotation of -118 , which was significantly lower in magnitude than that reported (-202). [4] We observed the same value in both our initial synthesis and the route disclosed here. Furthermore, we confirmed high isomeric purity, as judged by HPLC at several stages of the synthesis (compounds 30, 32, and 33). In order to confirm our results, we requested a sample of Aspergillus viridinutans from NRRL that was cultured and extracted as described by Lillehoj. Natural viriditoxin was purified by preparative HPLC and the optical rotation was measured as $[a]_{D}{ }^{22}-125$, comparable to the value we obtained for the synthetic sample. Both natural and synthetic (-)-viriditoxin yielded identical NMR spectra $\left({ }^{1} \mathrm{H}\right.$ and $\left.{ }^{13} \mathrm{C}\right)$ when analyzed separately. We conclude that experimental differences between the original measurement of the optical rotation and our measurements account for the observed difference.

\section{Conclusion}

Our second-generation synthesis of (-)-viriditoxin has allowed us to access larger quantities with greater efficiency. Synthesis of the key unsaturated lactone was achieved without the use of toxic alkyltin reagents. In addition, the use of RCM avoided the large-scale use of ozonolysis and a lithium enolate intermediate. Use of a TBDPS protecting group as a replacement for TIPS protection of the primary alcohol resulted in two important improvements: (1) greater stability toward phenolic EOM group removal during naphthopyranone assembly and (2) enhanced the diastereoselection of the biaryl bond forming step. Finally, we have addressed the discrepancy between the optical rotation values of synthetic and natural samples of viriditoxin. The results published here show significant improvements to our previous synthesis and will allow access to similar biaryl natural products and in-depth studies of their biological activity.

\section{Experimental Section}

All reactions were carried out under a argon atmosphere in flame-dried glassware with magnetic stirring. THF, $\mathrm{Et}_{2} \mathrm{O}, \mathrm{CH}_{2} \mathrm{Cl}_{2}$ were run through a pad of basic alumina prior to use. Reagents were purified immediately before use and following the guidelines of Perrin and 
Armarego. [33] Purification of products were carried out by flash chromatography unless otherwise stated using Silica gel 400 mesh obtained from EM science. Analytical TLC was performed on silica-gel $\mathrm{UV}^{254}$ precoated glass backbone. Visualization was accomplished with UV light and $\mathrm{KMnO}_{4} \cdot{ }^{1} \mathrm{H}$ NMR spectra were recorded on a Varian Unity Inova NMR spectrometers $(300 \mathrm{MHz}, 400 \mathrm{MHz}$ or $600 \mathrm{MHz})$ using solvent as internal standard $\left(\mathrm{CDCl}_{3}\right.$ $\delta=7.26 \mathrm{ppm}$ ). Proton-decoupled ${ }^{13} \mathrm{C}$ NMR spectra were recorded on a Varian Unity Inova NMR spectrometers $(75 \mathrm{MHz}, 100 \mathrm{MHz}$ or $150 \mathrm{MHz}$ ) using solvent as internal standard $\left(\mathrm{CDCl}_{3} \delta=77.0 \mathrm{ppm}\right)$. Infrared spectra were recorded on a Bruker Tensor $27 \mathrm{FT}-\mathrm{IR}$ spectrophotometer equipped with a DTGS detector and Smart Orbit bounce diamond ATR accessory. Mass spectra were obtained on a Thermo Fischer LTQ-Orbitrap mass spectrometer.

\section{(S)-1-(Triisopropylsiloxy)hex-5-en-3-yl Acrylate (12a)}

To a soln of $13 \mathbf{a}(5.0 \mathrm{~g}, 18.3 \mathrm{mmol})$ in $\mathrm{CH}_{2} \mathrm{Cl}_{2}(120 \mathrm{~mL})$ and acryloyl chloride $(2.9 \mathrm{~mL}$, $36.7 \mathrm{mmol})$ at $0{ }^{\circ} \mathrm{C}$ was added $\mathrm{Et}_{3} \mathrm{~N}(5.6 \mathrm{~mL}, 40.3 \mathrm{mmol})$ dropwise. The mixture was allowed to warm to r.t. over $2 \mathrm{~h}$ (TLC monitoring) and quenched with sat. $\mathrm{NaHCO}_{3}(100$ $\mathrm{mL})$. The layers were separated and the aqueous layer was extracted with $\mathrm{CH}_{2} \mathrm{Cl}_{2}(3 \times 20$ $\mathrm{mL})$. The combined organic layers were dried $\left(\mathrm{Na}_{2} \mathrm{SO}_{4}\right)$ and concentrated in vacuo. The residue was purified by flash column chromatography to give $12 \mathrm{a}(4.0 \mathrm{~g}, 12.25 \mathrm{mmol}, 66 \%)$ as a colorless oil; $[\mathrm{a}]_{\mathrm{D}}{ }^{22}+30.8\left(\mathrm{c} 0.57, \mathrm{CHCl}_{3}\right) ; \mathrm{R}_{\mathrm{f}}=0.65$ (hexane-EtOAc, 9:1).

IR (film): 2944, 2867, 1724, 1406, $1190 \mathrm{~cm}^{-1}$.

${ }^{1} \mathrm{H}$ NMR (400 MHz, $\left.\mathrm{CDCl}_{3}\right): \delta=1.06(\mathrm{~s}, 20 \mathrm{H}), 1.84(\mathrm{q}, \mathrm{J}=6.5 \mathrm{~Hz}, 2 \mathrm{H}), 2.40(\mathrm{~m}, 2 \mathrm{H})$, $3.73(\mathrm{t}, \mathrm{J}=6.5 \mathrm{~Hz}, 2 \mathrm{H}), 5.10(\mathrm{~m}, 4 \mathrm{H}), 5.77(\mathrm{~m}, 2 \mathrm{H}), 6.09(\mathrm{~m}, 1 \mathrm{H}), 6.37(\mathrm{~m}, 1 \mathrm{H})$.

${ }^{13} \mathrm{C}$ NMR $\left(100 \mathrm{MHz}, \mathrm{CDCl}_{3}\right): \delta=12.1,18.2,36.8,38.9,59.9,71.2,118.0,129.0,130.5$, 133.7, 165.9.

HRMS (ESI): $\mathrm{m} / \mathrm{z}[\mathrm{M}+\mathrm{H}]^{+}$calcd for $\mathrm{C}_{18} \mathrm{H}_{35} \mathrm{O}_{3} \mathrm{Si}: 327.2277$; found: 327.2354 .

\section{(S)-1-(tert-Butyldiphenylsiloxy)hex-5-en-3-yl Acrylate (12b)}

To a soln of 13b $(6.35 \mathrm{~g}, 17.9 \mathrm{mmol})$ and acryloyl chloride $(1.6 \mathrm{~mL}, 19.7 \mathrm{mmol})$ in THF (33 $\mathrm{mL})$ at $0{ }^{\circ} \mathrm{C}$ was added $\mathrm{Et}_{3} \mathrm{~N}(5.0 \mathrm{~mL}, 35.8 \mathrm{mmol})$ dropwise with vigorous stirring. The mixture was stirred for $1 \mathrm{~h}$ at $0{ }^{\circ} \mathrm{C}$ then warmed to r.t. and stirred for an additional $1.5 \mathrm{~h}$. The $\mathrm{Et}_{3} \mathrm{~N} \cdot \mathrm{HCl}$ was filtered off and washed with THF $(3 \times 20 \mathrm{~mL})$. The filtrate was dried $\left(\mathrm{Na}_{2} \mathrm{SO}_{4}\right)$ and concentrated in vacuo, and the residue was purified by flash column chromatography to give the corresponding olefin $(6.5 \mathrm{~g}, 15.9 \mathrm{mmol}, 89 \%)$ as a pale-yellow oil; $[a]_{\mathrm{D}}{ }^{22}+17.09\left(\mathrm{c} 0.772, \mathrm{CHCl}_{3}\right) ; \mathrm{R}_{\mathrm{f}}=0.83$ (hexane-EtOAc, 8:2).

IR (film): 3070, 2935, 2855, 1721, $1404 \mathrm{~cm}^{-1}$.

${ }^{1} \mathrm{H}$ NMR (400 MHz, $\mathrm{CDCl}_{3}$ ): $\delta=1.07$ (s, $\left.9 \mathrm{H}\right), 1.82-1.95$ (m, $\left.2 \mathrm{H}\right), 2.40$ (s, $\left.2 \mathrm{H}\right), 3.72$ (t, J $=6.3 \mathrm{~Hz}, 2 \mathrm{H}), 5.07(\mathrm{~d}, \mathrm{~J}=12.2 \mathrm{~Hz}, 2 \mathrm{H}), 5.19-5.32(\mathrm{~m}, 1 \mathrm{H}), 5.68-5.88(\mathrm{~m}, 2 \mathrm{H}), 6.08(\mathrm{~m}$, $1 \mathrm{H}), 6.31-6.44$ (m, $1 \mathrm{H}), 7.41(\mathrm{~m}, 6 \mathrm{H}), 7.67(\mathrm{~m}, 4 \mathrm{H})$.

${ }^{13} \mathrm{C} \mathrm{NMR}\left(100 \mathrm{MHz}, \mathrm{CDCl}_{3}\right): \delta=19.3,27.0,36.4,38.8,60.3,71.0,118.0,127.8,129.0$, $129.8,130.5,133.7,135.8,165.8$.

HRMS (ESI): $\mathrm{m} / \mathrm{z}[\mathrm{M}+\mathrm{H}]^{+}$calcd for $\mathrm{C}_{25} \mathrm{H}_{33} \mathrm{O}_{3} \mathrm{Si}: 409.2121$; found: 409.2194 . 


\section{(6S)-6-[2-(Triisopropylsiloxy)ethyl]-5,6-dihydro-2H-pyran-2-one (9a)}

To a soln of 12a $(4.0 \mathrm{~g}, 12.25 \mathrm{mmol})$ in $\mathrm{CH}_{2} \mathrm{Cl}_{2}(700 \mathrm{~mL})$ under argon was added dropwise a soln of Grubbs II catalyst $(0.21 \mathrm{~g}, 0.24 \mathrm{mmol})$ in $\mathrm{CH}_{2} \mathrm{Cl}_{2}(8 \mathrm{~mL})$, and the mixture was refluxed for $15 \mathrm{~h}$. The mixture was cooled to r.t. and tris(hydroxymethyl)phosphine ( $0.04 \mathrm{~g}$, $0.37 \mathrm{mmol})$ was added followed by $\mathrm{Et}_{3} \mathrm{~N}(0.30 \mathrm{~mL}, 2.9 \mathrm{mmol})$ and the mixture was stirred vigorously for $15 \mathrm{~h}$. Deionized $\mathrm{H}_{2} \mathrm{O}(500 \mathrm{~mL})$ was added and the mixture was stirred vigorously for $30 \mathrm{~min}$. The layers were separated and the organic layer was washed with deionized $\mathrm{H}_{2} \mathrm{O}(300 \mathrm{~mL})$ followed by $\mathrm{H}_{2} \mathrm{O}$-brine $(1: 1,250 \mathrm{~mL})$, dried $\left(\mathrm{Na}_{2} \mathrm{SO}_{4}\right)$, filtered, and concentrated in vacuo. The residue was purified by flash column chromatography to give $9 \mathrm{a}(3.5 \mathrm{~g}, 11.7 \mathrm{mmol}, 97 \%)$ as a colorless oil. Spectroscopic data were identical to those reported in the literature. [15]

\section{(6S)-6-[2-(tert-Butyldiphenylsiloxy)ethyl]-5,6-dihydro-2H-pyran-2-one (9b)}

To a soln of $\mathbf{1 2 b}(1.2 \mathrm{~g}, 2.94 \mathrm{mmol})$ in $\mathrm{CH}_{2} \mathrm{Cl}_{2}(200 \mathrm{~mL})$ under argon was added dropwise a soln of Grubbs II catalyst $(0.05 \mathrm{~g}, 0.058 \mathrm{mmol})$ in $\mathrm{CH}_{2} \mathrm{Cl}_{2}(2 \mathrm{~mL})$, and the mixture was refluxed for $15 \mathrm{~h}$. The mixture was cooled to r.t. and tris(hydroxymethyl)phosphine ( $0.01 \mathrm{~g}$, $0.09 \mathrm{mmol})$ was added followed by $\mathrm{Et}_{3} \mathrm{~N}(0.016 \mathrm{~mL}, 0.12 \mathrm{mmol})$ and the mixture was stirred vigorously for $15 \mathrm{~h}$. Deionized $\mathrm{H}_{2} \mathrm{O}(200 \mathrm{~mL})$ was added and the mixture was stirred vigorously for $30 \mathrm{~min}$. The layers were separated and the organic layer was washed with deionized $\mathrm{H}_{2} \mathrm{O}(150 \mathrm{~mL})$ followed by $\mathrm{H}_{2} \mathrm{O}$-brine $(1: 1,100 \mathrm{~mL})$, dried $\left(\mathrm{Na}_{2} \mathrm{SO}_{4}\right)$, filtered, and concentrated in vacuo. The residue was purified by flash column chromatography to give $9 b(1.0 \mathrm{~g}, 2.62 \mathrm{mmol}, 89 \%)$ as a light-yellow oil; $[\mathrm{a}]_{\mathrm{D}}{ }^{22}-32.59\left(\mathrm{c} 0.316, \mathrm{CHCl}_{3}\right) ; \mathrm{R}_{\mathrm{f}}=$ 0.33 (hexanes-EtOAc, 8:2).

IR (film): 2932, 2851, 1718, 1425, 1378, $1240 \mathrm{~cm}^{-1}$.

${ }^{1} \mathrm{H}$ NMR (400 MHz, CDCl $)$ ): $\delta=1.06$ (s, $\left.9 \mathrm{H}\right), 1.90$ (m, $\left.1 \mathrm{H}\right), 2.03$ (s, $\left.1 \mathrm{H}\right), 2.29-2.39$ (m, 2 H), $3.81(\mathrm{~m}, 1 \mathrm{H}), 3.91(\mathrm{~m}, 1 \mathrm{H}), 4.63-4.75(\mathrm{~m}, 1 \mathrm{H}), 6.02(\mathrm{~d}, \mathrm{~J}=9.8 \mathrm{~Hz}, 1 \mathrm{H}), 6.81-6.93$ $(\mathrm{m}, 1 \mathrm{H}), 7.41(\mathrm{~m}, 6 \mathrm{H}), 7.66(\mathrm{~m}, 4 \mathrm{H})$.

${ }^{13} \mathrm{C}$ NMR $\left(100 \mathrm{MHz}, \mathrm{CDCl}_{3}\right): \delta=19.4,27.1,29.7,37.8,59.6,75.3,121.6,128.0,130.0$, $133.7,135.7,145.4,164.6$.

HRMS (ESI): $\mathrm{m} / \mathrm{z}[\mathrm{M}+\mathrm{H}]^{+}$calcd for $\mathrm{C}_{23} \mathrm{H}_{29} \mathrm{O}_{3} \mathrm{Si}$ : 381.1881; found: 381.1878 .

\section{Dimethyl-2,2'-Ethylenebis[4-(ethoxymethoxy)-6-isopropoxybenzoate] (19)}

To a soln of i- $\mathrm{Pr}_{2} \mathrm{NH}(0.21 \mathrm{~mL}, 1.52 \mathrm{mmol})$ in THF $(3.6 \mathrm{~mL})$ at $0{ }^{\circ} \mathrm{C}$ was added $2.5 \mathrm{M} \mathrm{BuLi}$ in hexane $(0.58 \mathrm{~mL}, 1.46 \mathrm{mmol})$. The mixture was allowed to warm to r.t. and stirred for 30 min. After cooling to $-78{ }^{\circ} \mathrm{C}$, a soln of $8(0.17 \mathrm{~g}, 0.61 \mathrm{mmol})$ in THF $(1.0 \mathrm{~mL})$ was added dropwise and stirring was continued for $30 \mathrm{~min}$ at $-78^{\circ} \mathrm{C}$. DMPU $(0.14 \mathrm{~mL}, 1.22 \mathrm{mmol})$ was added dropwise and the soln was stirred for $20 \mathrm{~min}$. A soln of $17(0.20 \mathrm{~g}, 1.05 \mathrm{mmol})$ in THF $(1.0 \mathrm{~mL})$ was added dropwise into the soln and the mixture was stirred for $1 \mathrm{~h}$ at -78 ${ }^{\circ} \mathrm{C}$. Then, the resultant soln was allowed to warm slowly to r.t. and stirred overnight. The reaction was quenched with sat. $\mathrm{NH}_{4} \mathrm{Cl}$ and extracted with EtOAc $(3 \times 5 \mathrm{~mL})$. The combine organic extracts were washed with brine, dried $\left(\mathrm{Na}_{2} \mathrm{SO}_{4}\right)$, filtered, and concentrated in vacuo. The coupled dimer was purified (silica gel) and isolated $(0.056 \mathrm{~g}, 0.10 \mathrm{mmol}, 33 \%$ yield) as an orange solid.

IR (film): 2866, 1714, 1600, $1277 \mathrm{~cm}^{-1}$. 
${ }^{1} \mathrm{H}$ NMR $\left(400 \mathrm{MHz}, \mathrm{CDCl}_{3}\right): \delta=1.21(\mathrm{t}, \mathrm{J}=7.1 \mathrm{~Hz}, 3 \mathrm{H}), 1.30(\mathrm{~d}, \mathrm{~J}=6.1 \mathrm{~Hz}, 6 \mathrm{H}), 2.76(\mathrm{~s}$, $2 \mathrm{H}), 3.70$ (q, J = 7.1 Hz, $2 \mathrm{H}), 3.89(\mathrm{~s}, 3 \mathrm{H}), 4.40-4.55(\mathrm{~m}, 1 \mathrm{H}), 5.18(\mathrm{~s}, 2 \mathrm{H}), 6.47$ (dd, J = $2.1,10.4 \mathrm{~Hz}, 2 \mathrm{H})$.

${ }^{13} \mathrm{C} \mathrm{NMR}\left(100 \mathrm{MHz}, \mathrm{CDCl}_{3}\right): \delta=12.1,15.3,18.2,22.2,35.9,52.2,64.4,71.6,93.2,100.8$, $118.9,141.5,156.5,159.2,168.9$.

HRMS (ESI): $\mathrm{m} / \mathrm{z}[\mathrm{M}+\mathrm{Na}]^{+}$calcd for $\mathrm{C}_{30} \mathrm{H}_{42} \mathrm{NaO}_{10}$ : 585.2670; found: 585.2663.

\section{(3S)-3-[2-(tert-Butyldiphenylsiloxy)ethyl]-7-(ethoxymethoxy)-10-hydroxy-9-isopropoxy-3,4- dihydro-1H-naphtho[2,3-c]pyran-1-one (20b)}

To a soln of i- $\mathrm{Pr}_{2} \mathrm{NH}(0.32 \mathrm{~mL}, 2.28 \mathrm{mmol})$ in THF $(5 \mathrm{~mL})$ at $0{ }^{\circ} \mathrm{C}$ was added $2.5 \mathrm{M} \mathrm{BuLi}$ in hexane $(0.87 \mathrm{~mL}, 2.19 \mathrm{mmol})$. The mixture was allowed to warm to r.t. and stirred for 30 min. After cooling to $-78{ }^{\circ} \mathrm{C}$, a soln of ester $8(0.26 \mathrm{~g}, 0.91 \mathrm{mmol})$ in THF $(1 \mathrm{~mL})$ was added dropwise and stirring was continued for $30 \mathrm{~min}$ at $-78{ }^{\circ} \mathrm{C}$. DMPU $(0.22 \mathrm{~mL}, 1.82$ $\mathrm{mmol}$ ) was added dropwise and the mixture was stirred for $20 \mathrm{~min}$. A soln of lactone $\mathbf{9 b}$ $(0.38 \mathrm{~g}, 1.00 \mathrm{mmol})$ in THF $(1 \mathrm{~mL})$ was added dropwise and the mixture was stirred for $1 \mathrm{~h}$ at $-78{ }^{\circ} \mathrm{C}$. Then, the resultant soln was allowed to warm slowly to r.t. and stirred for $15 \mathrm{~h}$. The reaction was quenched with sat. $\mathrm{NH}_{4} \mathrm{Cl}(10 \mathrm{~mL})$ and extracted with EtOAc $(3 \times 5 \mathrm{~mL})$. The combined organic extracts were washed with brine, dried $\left(\mathrm{Na}_{2} \mathrm{SO}_{4}\right)$, filtered, and concentrated in vacuo. The residue was filtered through a silica gel plug (hexane-EtOAc, $8: 2$ ) and used immediately in the next step.

To a soln of the tricycle $(0.3 \mathrm{~g}, 0.47 \mathrm{mmol})$ in benzene $(8 \mathrm{~mL})$ was added a soln of DDQ $(0.17 \mathrm{~g}, 0.76 \mathrm{mmol})$ in benzene $(4 \mathrm{~mL})$ dropwise at r.t. After stirring for $4 \mathrm{~h}$, the reaction was quenched with sat. $\mathrm{NaHCO}_{3}(30 \mathrm{~mL})$ and then it was stirred vigorously for $1 \mathrm{~h}$. The mixture was extracted with $\mathrm{Et}_{2} \mathrm{O}(3 \times 15 \mathrm{~mL})$. The combined organic layers were washed with brine $(30 \mathrm{~mL})$, dried $\left(\mathrm{Na}_{2} \mathrm{SO}_{4}\right)$, filtered, and concentrated in vacuo. The residue was purified by flash column chromatography to give $\mathbf{2 0 b}(0.3 \mathrm{~g}, 0.47 \mathrm{mmol}, 53 \%$, two steps) as a clear oil; $[\mathrm{a}]_{\mathrm{D}}{ }^{25}+31.3\left(\mathrm{c} 0.16, \mathrm{CHCl}_{3}\right) ; \mathrm{R}_{\mathrm{f}}=0.46$ (hexane-EtOAc, 8:2).

IR (film): 3062, 2954, 1738, 1600, $1370 \mathrm{~cm}^{-1}$.

${ }^{1} \mathrm{H} \mathrm{NMR}\left(600 \mathrm{MHz}, \mathrm{CDCl}_{3}\right): \delta=1.07(\mathrm{~s}, 9 \mathrm{H}), 1.26(\mathrm{t}, \mathrm{J}=7.1 \mathrm{~Hz}, 3 \mathrm{H}), 1.49(\mathrm{~d}, \mathrm{~J}=6.0 \mathrm{~Hz}$, $6 \mathrm{H}), 2.05(\mathrm{~s}, 2 \mathrm{H}), 2.99(\mathrm{~s}, 2 \mathrm{H}), 3.78(\mathrm{q}, \mathrm{J}=7.1 \mathrm{~Hz}, 2 \mathrm{H}), 3.87(\mathrm{~m}, 1 \mathrm{H}), 3.96(\mathrm{~m}, 1 \mathrm{H})$, 4.62-4.75 (m, $1 \mathrm{H}), 4.80(\mathrm{~m}, 1 \mathrm{H}), 5.33(\mathrm{~s}, 2 \mathrm{H}), 6.60(\mathrm{~d}, \mathrm{~J}=2.1 \mathrm{~Hz}, 1 \mathrm{H}), 6.79-6.90(\mathrm{~m}, 2$ $\mathrm{H}), 7.42(\mathrm{~m}, 6 \mathrm{H}), 7.68(\mathrm{~m}, 4 \mathrm{H}), 12.85(\mathrm{~s}, 1 \mathrm{H})$.

${ }^{13} \mathrm{C}$ NMR $\left(125 \mathrm{MHz}, \mathrm{CDCl}_{3}\right): \delta=15.4,19.4,22.1,27.1,33.9,37.8,59.7,64.8,72.5,76.5$, 93.2, 101.4, 102.1, 102.7, 112.3, 115.6, 128.0, 130.0, 133.5, 133.7, 135.7, 141.4, 159.1, $159.4,164.3,170.5$.

HRMS (ESI): $\mathrm{m} / \mathrm{z}[\mathrm{M}+\mathrm{H}]^{+}$calcd for $\mathrm{C}_{37} \mathrm{H}_{45} \mathrm{O}_{7} \mathrm{Si}: 629.2856$; found: 629.2934 .

(3S)-3-[2-(tert-Butyldiphenylsiloxy)ethyl]-7-(ethoxymethoxy)-9-isopropoxy-10-methoxy-3,4dihydro-1H-naphtho[2,3-c]pyran-1-one (7b)

To a soln of $20 \mathrm{~b}(0.43 \mathrm{~g}, 0.68 \mathrm{mmol})$ and $\mathrm{K}_{2} \mathrm{CO}_{3}(0.26 \mathrm{~g}, 2.05 \mathrm{mmol})$ in acetone $(10 \mathrm{~mL})$ was added dimethyl sulfate $(0.19 \mathrm{~mL}, 2.05 \mathrm{mmol})$ and the resulting mixture was heated at $60{ }^{\circ} \mathrm{C}$ for $15 \mathrm{~h}$. After the soln was cooled to r.t., the soln was filtered and the filter cake was washed with EtOAc $(30 \mathrm{~mL})$. Solvent was removed under reduced pressure, and the residue was purified by flash column chromatography to give $7 \mathbf{b}(0.33 \mathrm{~g}, 0.51 \mathrm{mmol}, 75 \%)$ as a pale-yellow oil; $[\mathrm{a}]_{\mathrm{D}}{ }^{22}-31.4\left(\mathrm{c} 0.70, \mathrm{CHCl}_{3}\right) ; \mathrm{R}_{\mathrm{f}}=0.30$ (hexane-EtOAc, 8:2). 
IR (film): 2935, 2851, 1714, 1613, $1563 \mathrm{~cm}^{-1}$.

${ }^{1} \mathrm{H} \mathrm{NMR}\left(600 \mathrm{MHz}, \mathrm{CDCl}_{3}\right): \delta=1.03(\mathrm{~s}, 9 \mathrm{H}), 1.24(\mathrm{t}, \mathrm{J}=7.1 \mathrm{~Hz}, 3 \mathrm{H}), 1.46(\mathrm{~d}, \mathrm{~J}=6.0 \mathrm{~Hz}$, $6 \mathrm{H}), 1.93(\mathrm{~m}, 1 \mathrm{H}), 2.07(\mathrm{~m}, 1 \mathrm{H}), 2.93-3.03(\mathrm{~m}, 2 \mathrm{H}), 3.76(\mathrm{q}, \mathrm{J}=7.1 \mathrm{~Hz}, 2 \mathrm{H}), 3.82-3.87$ (m, $1 \mathrm{H}), 3.93(\mathrm{~s}, 3 \mathrm{H}), 3.95(\mathrm{~m}, 1 \mathrm{H}), 4.70(\mathrm{~m}, 2 \mathrm{H}), 5.32(\mathrm{~s}, 2 \mathrm{H}), 6.59(\mathrm{~d}, \mathrm{~J}=2.1 \mathrm{~Hz}, 1 \mathrm{H})$, $6.88(\mathrm{~d}, \mathrm{~J}=2.2 \mathrm{~Hz}, 1 \mathrm{H}), 7.18$ (s, $1 \mathrm{H}), 7.33-7.46(\mathrm{~m}, 6 \mathrm{H}), 7.65$ (m, $4 \mathrm{H})$.

${ }^{13} \mathrm{C}$ NMR $\left(125 \mathrm{MHz}, \mathrm{CDCl}_{3}\right): \delta=15.3,19.4,21.8,27.1,35.0,37.8,58.8,59.9,63.6,64.8$, $71.0,75.1,93.2,101.8,113.7,117.1,120.9,127.9,129.9,133.6,133.7,140.7,157.4,158.4$, 162.5, 163.0.

HRMS (ESI): m/z [M + H] ${ }^{+}$calcd for $\mathrm{C}_{38} \mathrm{H}_{47} \mathrm{O}_{7} \mathrm{Si}: 643.3013$; found: 643.3087 .

(3S)-3-[2-(tert-Butyldiphenylsiloxy)ethyl]-7-hydroxy-9-isopropoxy-10-methoxy-3,4dihydro-1H-naphtho[2,3-c]pyran-1-one (29b)

To a soln of $7 \mathbf{b}(0.1 \mathrm{~g}, 0.15 \mathrm{mmol})$ in $\mathrm{CH}_{2} \mathrm{Cl}_{2}(1 \mathrm{~mL})$ was added $\mathrm{ZnBr}(0.03 \mathrm{~g}, 0.15 \mathrm{mmol})$ (Note: $\mathrm{ZnBr}_{2}$ must be dry) followed by $\mathrm{n}-\mathrm{PrSH}(0.03 \mathrm{~mL}, 0.31 \mathrm{mmol})$ at r.t. under argon. The mixture was stirred (TLC monitoring), after the starting material was consumed, the mixture was diluted with $\mathrm{CH}_{2} \mathrm{Cl}_{2}(4 \mathrm{~mL})$ brought down to $0{ }^{\circ} \mathrm{C}$, quenched with sat.

$\mathrm{NaHCO}_{3}(15 \mathrm{~mL})$, and filtered through Celite. The layers were separated and the aqueous layer was extracted with $\mathrm{CH}_{2} \mathrm{Cl}_{2}(3 \times 5 \mathrm{~mL})$. The combined organic layers were dried $\left(\mathrm{Na}_{2} \mathrm{SO}_{4}\right)$ and concentrated in vacuo. The residue was purified by flash column chromatography to give $29 \mathrm{~b}(0.086 \mathrm{~g}, 0.147 \mathrm{mmol}, 95 \%)$ as a colorless oil; $[\mathrm{a}]_{\mathrm{D}}{ }^{22}-57.0$ (c $0.71, \mathrm{CHCl}_{3}$ ); $\mathrm{R}_{\mathrm{f}}=0.5$ (hexane-EtOAc, $6: 4$ ).

IR (film): 2935, 2857, 1688, 1610, $1562 \mathrm{~cm}^{-1}$.

${ }^{1} \mathrm{H}$ NMR $\left(600 \mathrm{MHz}, \mathrm{CDCl}_{3}\right): \delta=1.02(\mathrm{~s}, 9 \mathrm{H}), 1.44(\mathrm{~d}, \mathrm{~J}=5.9 \mathrm{~Hz}, 6 \mathrm{H}), 1.83-1.98(\mathrm{~m}, 1$ H), $2.05(\mathrm{~m}, 1 \mathrm{H}), 2.96(\mathrm{~m}, 2 \mathrm{H}), 3.75-3.88(\mathrm{~m}, 1 \mathrm{H}), 3.97(\mathrm{~s}, 4 \mathrm{H}), 4.68(\mathrm{~m}, 2 \mathrm{H}), 6.51(\mathrm{~s}, 1$ H), $6.65(\mathrm{~s}, 1 \mathrm{H}), 7.06(\mathrm{~s}, 1 \mathrm{H}), 7.38(\mathrm{~m}, 6 \mathrm{H}), 7.65(\mathrm{~m}, 4 \mathrm{H})$.

${ }^{13} \mathrm{C}$ NMR $\left(125 \mathrm{MHz}, \mathrm{CDCl}_{3}\right): \delta=19.4,21.9,27.0,34.8,37.7,59.8,63.5,71.0,75.4,101.3$, $102.3,112.4,116.1,120.3,127.9,129.9,133.8,135.7,141.3,156.4,157.8,158.3,162.8$, 164.2.

HRMS (ESI): $\mathrm{m} / \mathrm{z}$ [M $+\mathrm{H}]^{+}$calcd for $\mathrm{C}_{35} \mathrm{H}_{41} \mathrm{O}_{6} \mathrm{Si}$ : 585.2594; found: 585.2667.

\section{( $\left.R_{a}, 3 S, 3 ' S\right)-3,3 '-B i s[2-(t e r t-b u t y l d i p h e n y l s i l o x y) e t h y l]-7,7 '$ '-dihydroxy-9,9'- diisopropoxy-10,10'-dimethoxy-3,3',4,4'-tetrahydro-6,6'-bi[1H-naphtho[2,3-c]pyran]-1,1'- dione (30)}

To a soln of $29 \mathrm{~b}(0.086 \mathrm{~g}, 0.147 \mathrm{mmol})$ in $\mathrm{CH}_{2} \mathrm{Cl}_{2}(4 \mathrm{~mL})$ was added $\left(\mathrm{S}_{\mathrm{a}}, \mathrm{R}\right)-31 \mathrm{a}(0.02 \mathrm{~g}$, $0.029 \mathrm{mmol}, 20 \mathrm{~mol} \%$ ); the flask was kept under an $\mathrm{O}_{2}$ atmosphere and stirred at r.t. for 15 $\mathrm{h}$. The crude mixture was flushed through a silica gel plug before purification by flash column chromatography to give $\mathbf{3 0}(0.05 \mathrm{~g}, 0.043 \mathrm{mmol}, 65 \%)$ as a colorless oil; $[\mathrm{a}]_{\mathrm{D}}{ }^{22}$ $-33.0\left(\mathrm{c} 0.024, \mathrm{CHCl}_{3}\right) ; \mathrm{R}_{\mathrm{f}}=0.56$ (benzene-acetone 8:2).

IR (film): 3370, 2930, 2856, 2371, 1716, $1613 \mathrm{~cm}^{-1}$.

${ }^{1} \mathrm{H}$ NMR $\left(600 \mathrm{MHz}, \mathrm{CDCl}_{3}\right): \delta=0.98(\mathrm{~s}, 9 \mathrm{H}), 1.56(\mathrm{dd}, \mathrm{J}=6.0,9.7 \mathrm{~Hz}, 6 \mathrm{H}), 1.83(\mathrm{~m}, 1$ H), $2.00(\mathrm{~m}, 1 \mathrm{H}), 2.74(\mathrm{~m}, 2 \mathrm{H}), 3.69-3.77(\mathrm{~m}, 1 \mathrm{H}), 3.92(\mathrm{~m}, 1 \mathrm{H}), 4.06(\mathrm{~s}, 3 \mathrm{H}), 4.60(\mathrm{~m}, 1$ H), 4.78-4.88 (m, $1 \mathrm{H}), 5.40(\mathrm{~s}, 1 \mathrm{H}), 6.60(\mathrm{~s}, 1 \mathrm{H}), 6.77(\mathrm{~s}, 1 \mathrm{H}), 7.28-7.45(\mathrm{~m}, 6 \mathrm{H}), 7.60$ (m, $4 \mathrm{H})$. 
${ }^{13} \mathrm{C}$ NMR $\left(125 \mathrm{MHz}, \mathrm{CDCl}_{3}\right): \delta=19.3,22.0,27.1,35.2,37.8,59.6,63.7,71.2,75.0,99.3$, $102.3,114.0,117.5,127.9,128.0,128.5,133.5,138.3,140.0,156.8,159.3,162.9,163.2$.

HRMS (ESI): $\mathrm{m} / \mathrm{z}[\mathrm{M}+\mathrm{H}]^{+}$calcd for $\mathrm{C}_{70} \mathrm{H}_{79} \mathrm{O}_{12} \mathrm{Si}_{2}: 1167.5032$; found: 1167.5124 .

\section{( $\mathrm{S}_{\mathrm{a}}, 3 \mathrm{~S}, 3$ 'S)-3,3'-Bis[2-(tert-butyldiphenylsiloxy)ethyl]-7,7'-dihydroxy-9,9'- diisopropoxy-10,10'-dimethoxy-3,3',4,4'-tetrahydro-6,6'-bi[1H-naphtho[2,3-c]pyran]-1,1'- dione $\left(30^{\prime}\right)$}

To a soln of $29 \mathbf{b}(0.05 \mathrm{~g}, 0.085 \mathrm{mmol})$ in $\mathrm{CH}_{2} \mathrm{Cl}_{2}(2 \mathrm{~mL})$ was added $\left(\mathrm{S}_{\mathrm{a}}, \mathrm{S}\right)-31 \mathrm{a}(0.01 \mathrm{~g}$, $0.017 \mathrm{mmol}, 20 \mathrm{~mol} \%$ ); the flask was kept under an $\mathrm{O}_{2}$ atmosphere and stirred at r.t. for 15 $\mathrm{h}$. The crude mixture was flushed through a silica gel plug before purification by flash column chromatography to give $\mathbf{3 0}^{\prime}(0.045 \mathrm{~g}, 0.038 \mathrm{mmol}, 90 \%)$ as a colorless oil; [a $]_{\mathrm{D}}{ }^{24}$ $-41.0\left(\mathrm{c} 0.16, \mathrm{CHCl}_{3}\right) ; \mathrm{R}_{\mathrm{f}}=0.2$ (benzene-acetone 8:2).

IR (film): 3345, 2933, 2859, 2361, 1716, $1614 \mathrm{~cm}^{-1}$.

${ }^{1} \mathrm{H}$ NMR $\left(600 \mathrm{MHz}, \mathrm{CDCl}_{3}\right): \delta=0.92,(\mathrm{~s}, 18 \mathrm{H}), 1.56(\mathrm{dd}, \mathrm{J}=6.0 \mathrm{~Hz}, 7.6,12 \mathrm{H}), 1.82(\mathrm{~m}, 2$ H), 2.00 (m, 2 H), $2.79(\mathrm{~m}, 4 \mathrm{H}), 3.69-3.75(\mathrm{~m}, 2 \mathrm{H}), 3.84(\mathrm{~m}, 2 \mathrm{H}), 4.05(\mathrm{~s}, 6 \mathrm{H}), 4.52(\mathrm{~m}, 2$ H), $4.84(\mathrm{~m}, 2 \mathrm{H}), 5.21(\mathrm{~s}, 2 \mathrm{H}), 6.67(\mathrm{~s}, 2 \mathrm{H}), 6.74(\mathrm{~s}, 2 \mathrm{H}), 7.22-7.39(\mathrm{~m}, 16 \mathrm{H}), 7.56(\mathrm{~m}, 4$ H).

${ }^{13} \mathrm{C}$ NMR $\left(125 \mathrm{MHz}, \mathrm{CDCl}_{3}\right): \delta=19.0,21.6,21.9,26.7,34.8,37.5,59.5,63.5,71.0,74.6$, $99.2,101.7,113.7,116.9,117.2,127.6,129.6,133.2,138.1,139.5,156.9,159.1,162.5$, 163.1 .

HRMS (ESI): $\mathrm{m} / \mathrm{z}[\mathrm{M}+\mathrm{H}]^{+}$calcd for $\mathrm{C}_{70} \mathrm{H}_{79} \mathrm{O}_{12} \mathrm{Si}_{2}: 1167.5105$; found: 1167.5125.

\section{( $R_{a}, 3 S, 3$ 'S)-3,3'-Bis[2-(tert-butyldiphenylsiloxy)ethyl]-9,9'-diisopropoxy-7,7',10,10'- tetramethoxy-3,3',4,4'-tetrahydro-6,6'-bi[1H-naphtho[2,3-c]pyran]-1,1'-dione (32)}

To a soln of $\mathbf{3 0}(0.06 \mathrm{~g}, 0.05 \mathrm{mmol})$ in acetone $(2 \mathrm{~mL})$ was added $\mathrm{K}_{2} \mathrm{CO}_{3}(0.05 \mathrm{~g}, 0.40$ $\mathrm{mmol})$ followed by dimethyl sulfate $(0.04 \mathrm{~mL}, 0.40 \mathrm{mmol})$; the reaction was stirred at r.t. for $15 \mathrm{~h}$. The mixture was filtered and the filter cake was washed with acetone $(3 \times 5 \mathrm{~mL})$. The residue was purified by flash column chromatography to give $32(0.04 \mathrm{~g}, 0.033 \mathrm{mmol}, 65 \%)$ as a colorless oil; $[\mathrm{a}]_{\mathrm{D}}{ }^{25}-36.4\left(\mathrm{c} 0.022, \mathrm{CHCl}_{3}\right) ; \mathrm{R}_{\mathrm{f}}=0.37$ (hexane-EtOAc, 6:4).

IR (film): 2928, 2855, 1720, $1613 \mathrm{~cm}^{-1}$.

${ }^{1} \mathrm{H}$ NMR $\left(600 \mathrm{MHz}, \mathrm{CDCl}_{3}\right): \delta=0.97(\mathrm{~s}, 18 \mathrm{H}), 1.58(\mathrm{dd}, \mathrm{J}=3.8,5.9 \mathrm{~Hz}, 12 \mathrm{H}), 1.74-1.91$ (m, $2 \mathrm{H}), 2.05$ (m, $2 \mathrm{H}), 2.69$ (m, $4 \mathrm{H}), 3.73(\mathrm{~m}, 2 \mathrm{H}), 3.81(\mathrm{~s}, 6 \mathrm{H}), 3.85-3.96(\mathrm{~m}, 2 \mathrm{H}), 4.06$ (s, $6 \mathrm{H}), 4.51-4.63(\mathrm{~m}, 2 \mathrm{H}), 4.87(\mathrm{~m}, 2 \mathrm{H}), 6.57(\mathrm{~s}, 2 \mathrm{H}), 6.83(\mathrm{~s}, 2 \mathrm{H}), 7.33(\mathrm{~m}, 12 \mathrm{H}), 7.59$ (m, $8 \mathrm{H})$.

${ }^{13} \mathrm{C}$ NMR $\left(125 \mathrm{MHz}, \mathrm{CDCl}_{3}\right): \delta=19.3,22.3,27.0,35.3,37.8,56.7,59.7,63.6,71.5,75.0$, $97.7,110.9,113.2,116.9,118.4,127.8,127.9,129.9,133.5,135.6,139.8,157.9,158.5$, 162.9, 163.3.

HRMS (ESI): $\mathrm{m} / \mathrm{z}[\mathrm{M}+\mathrm{H}]^{+}$calcd for $\mathrm{C}_{72} \mathrm{H}_{83} \mathrm{O}_{12} \mathrm{Si}_{2}$ : 1195.5345 ; found: 1195.5435 .

\section{( $\left.\mathrm{S}_{\mathrm{a}}, 3 \mathrm{~S}, 3^{\prime} \mathrm{S}\right)$-3,3'-Bis[2-(tert-butyldiphenylsiloxy)ethyl]-9,9'-diisopropoxy-7,7',10,10'- tetramethoxy-3,3',4,4'-tetrahydro-6,6'-bi[1H-naphtho[2,3-c]pyran]-1,1'-dione (32')}

To a soln of $\mathbf{3 0}^{\prime}(0.045 \mathrm{~g}, 0.038 \mathrm{mmol})$ in acetone $(2 \mathrm{~mL})$ was added $\mathrm{K}_{2} \mathrm{CO}_{3}(0.04 \mathrm{~g}, 0.30$ $\mathrm{mmol}$ ) followed by dimethyl sulfate $(0.03 \mathrm{~mL}, 0.30 \mathrm{mmol})$, the reaction was stirred at r.t. for $15 \mathrm{~h}$. The mixture was filtered and the filter cake was washed with acetone $(3 \times 5 \mathrm{~mL})$. The 
residue was purified by flash column chromatography to give $\mathbf{3 2}^{\prime}(0.04 \mathrm{~g}, 0.033 \mathrm{mmol}$, $87 \%$ ) as a pale-yellow oil; $[\mathrm{a}]_{\mathrm{D}}{ }^{25}-27.8\left(\mathrm{c} 0.334, \mathrm{CHCl}_{3}\right) ; \mathrm{R}_{\mathrm{f}}=0.23$ (hexane-EtOAc, 6:4).

IR (film): 2927, 2854, 1731, 1617, 1568, $1331 \mathrm{~cm}^{-1}$.

${ }^{1} \mathrm{H} \mathrm{NMR}\left(600 \mathrm{MHz}, \mathrm{CDCl}_{3}\right): \delta=0.92(\mathrm{~s}, 18 \mathrm{H}), 1.56(\mathrm{~m}, 12 \mathrm{H}), 1.82(\mathrm{~m}, 2 \mathrm{H}), 1.99(\mathrm{~m}, 2$ H), $2.76(\mathrm{~m}, 4 \mathrm{H}), 3.73(\mathrm{~s}, 8 \mathrm{H}), 3.85(\mathrm{~m}, 2 \mathrm{H}), 4.06(\mathrm{~s}, 6 \mathrm{H}), 4.50(\mathrm{~m}, 2 \mathrm{H}), 4.85(\mathrm{~m}, 2 \mathrm{H})$, $6.65(\mathrm{~s}, 2 \mathrm{H}), 6.79(\mathrm{~s}, 2 \mathrm{H}), 7.28(\mathrm{~m}, 12 \mathrm{H}), 7.56(\mathrm{~m}, 8 \mathrm{H})$.

${ }^{13} \mathrm{C}$ NMR $\left(125 \mathrm{MHz}, \mathrm{CDCl}_{3}\right): \delta=19.0,21.8,21.8,22.1,26.7,29.6,34.9,37.5,56.3,59.5$, $63.4,71.2,74.7,97.5,110.7,112.9,116.7,118.1,127.6,129.6,133.2,135.3,139.7,157.6$, 158.1, 162.7 .

HRMS (ESI): $\mathrm{m} / \mathrm{z}[\mathrm{M}+\mathrm{H}]^{+}$calcd for $\mathrm{C}_{72} \mathrm{H}_{82} \mathrm{O}_{12} \mathrm{Si}_{2}: 1195.5418$; found: 1195.5443 .

\section{(Ra,3S,3'S)-3,3'-Bis(2-hydroxyethyl)-9,9'-diisopropoxy-7,7',10,10'-tetramethoxy-3,3',4,4'- tetrahydro-6,6'-bi[1H-naphtho[2,3-c]pyran]-1,1'-dione (33)}

To a soln of $32(0.04 \mathrm{~g}, 0.033 \mathrm{mmol})$ in THF $(1 \mathrm{~mL})$ was added TBAF $(1.67 \mathrm{~mL}, 1.67$ $\mathrm{mmol})$ at $0{ }^{\circ} \mathrm{C}$. The mixture was allowed to warm to r.t. and stirred for $2 \mathrm{~h}$. The mixture was quenched with sat. $\mathrm{NH}_{4} \mathrm{Cl}$ soln $(1 \mathrm{~mL})$ and diluted with EtOAc $(5 \mathrm{~mL})$. The layers were separated and the aqueous phase was washed with EtOAc $(3 \times 2 \mathrm{~mL})$. The combined organic layers were washed with $\mathrm{H}_{2} \mathrm{O}(5 \mathrm{~mL})$ and brine, and dried $\left(\mathrm{Na}_{2} \mathrm{SO}_{4}\right)$. The solvent removed in vacuo, and the residue was purified by flash column chromatography to give $\mathbf{3 3}$ $(0.02 \mathrm{~g}, 0.027 \mathrm{mmol}, 83 \%)$ as a white solid; $\mathrm{R}_{\mathrm{f}}=0.2($ EtOAc $100 \%)$. Spectroscopic data were identical to those reported in the literature. [15]

\section{$\left(S_{a}, 3 S, 3 ' S\right)-3,3^{\prime}-$ Bis(2-hydroxyethyl)-9,9'-diisopropoxy-7,7',10,10'-tetramethoxy-3,3',4,4'- tetrahydro-6,6'-bi[1H-naphtho[2,3-c]pyran]-1,1'-dione (33')}

To a soln of 32' $(0.04 \mathrm{~g}, 0.033 \mathrm{mmol})$ in THF $(1 \mathrm{~mL})$ was added TBAF $(1.67 \mathrm{~mL}, 1.67$ $\mathrm{mmol})$ at $0{ }^{\circ} \mathrm{C}$; the mixture was allowed to warm to r.t. and stirred for $2 \mathrm{~h}$. The mixture was quenched with sat. $\mathrm{NH}_{4} \mathrm{Cl}$ soln $(1 \mathrm{~mL})$ and diluted with EtOAc $(5 \mathrm{~mL})$. The layers were separated and the aqueous phase was washed with EtOAc $(3 \times 2 \mathrm{~mL})$. The combined organic layers were washed with $\mathrm{H}_{2} \mathrm{O}(5 \mathrm{~mL})$ and brine, and dried $\left(\mathrm{Na}_{2} \mathrm{SO}_{4}\right)$. The solvent removed in vacuo, and the residue was purified by flash column chromatography to give $\mathbf{3 3}^{\prime}$ $(0.02 \mathrm{~g}, 0.027 \mathrm{mmol}, 83 \%)$ as a white solid; $[\mathrm{a}]_{\mathrm{D}}{ }^{25}-22\left(\mathrm{c} 0.05, \mathrm{CHCl}_{3}\right) ; \mathrm{R}_{\mathrm{f}}=0.2(\mathrm{EtOAc}$ $100 \%)$.

IR (film): 3403, 2927, 2852, 2361, 2346, $1720 \mathrm{~cm}^{-1}$.

${ }^{1} \mathrm{H}$ NMR (600 MHz, $\left.\mathrm{CDCl}_{3}\right): \delta=1.56(\mathrm{dd}, \mathrm{J}=2.5,6.0 \mathrm{~Hz}, 12 \mathrm{H}), 1.84(\mathrm{~m}, 2 \mathrm{H}), 2.00(\mathrm{~m}, 2$ H), $2.76(\mathrm{~m}, 4 \mathrm{H}), 3.76(\mathrm{~s}, 6 \mathrm{H}), 3.80(\mathrm{~m}, 2 \mathrm{H}), 3.89(\mathrm{~m}, 2 \mathrm{H}), 4.06(\mathrm{~s}, 6 \mathrm{H}), 4.52(\mathrm{~m}, 2 \mathrm{H})$, 4.85 (m, 2 H), 6.57 (s, $2 \mathrm{H}), 6.79$ (s, $2 \mathrm{H})$.

${ }^{13} \mathrm{C}$ NMR $\left(125 \mathrm{MHz}, \mathrm{CDCl}_{3}\right): \delta=21.8,22.1,35.0,37.2,56.3,58.7,63.4,71.2,75.2,97.5$, $110.6,112.8,116.6,118.1,136.0,139.6,157.63,158.2,162.7,162.8$.

HRMS (ESI): $\mathrm{m} / \mathrm{z}[\mathrm{M}+\mathrm{H}]^{+}$calcd for $\mathrm{C}_{40} \mathrm{H}_{47} \mathrm{O}_{12}$ : 719.3062; found: 719.3072

\section{References}

1. Lock RL, Harry EJ. Nat Rev Drug Discovery. 2008; 7:324.

2. Erickson HP, Anderson DE, Osawa M. Microbiol Mol Biol Rev. 2010; 74:504. [PubMed: 21119015] 
3a. RayChaudhuri D, Park JT. Nature (London). 1992; 359:251. [PubMed: 1528267]

3b. De Boer P, Crossley R, Rothfield L. Nature (London). 1992; 359:254. [PubMed: 1528268]

3c. Mukherjee A, Dai K, Lutkenhaus J. Proc Natl Acad Sci USA. 1993; 90:1053. [PubMed: 8430073]

3d. Foss M, Eun Y-J, Weibel DB. Biochemistry. 2011; 50:7719. [PubMed: 21823588]

4. Weisleder D, Lillehoj EB. Tetrahedron Lett. 1971; 12:4705.

5. Suzuki K, Nozawa K, Nakajima S, Kawai K. Chem Pharm Bull. 1990; 38:3180.

6. Wang J, Galgoci A, Kodali S, Herath KB, Jayasuriya H, Dorso K, Vicente F, Gonzalez A, Cully D, Bramhill D, Singh S. J Biol Chem. 2003; 278:44424. [PubMed: 12952956]

7. Hood RD, Hayes AW, Scammell JG. Food Cosmet Toxicol. 1976; 14:175. [PubMed: 950209]

8. Arone A, Assante G, Montorsi M, Nasini G. Phytochemistry. 1995; 38:595.

9. Elix JA, Wardlaw JH. Aust J Chem. 2004; 57:681.

10. Suzuki K, Nozawa K, Nakajima S, Udagawa S, Kawai K. Chem Pharm Bull. 1992; 40:1116. [PubMed: 1394627]

11a. Ng AS, Just G, Blank F. Can J Chem. 1969; 47:1223.

11b. Blank F, Ng AS, Just G. Can J Chem. 1966; 44:2873.

12a. Matsumoto M, Minato H, Kondo E, Mitsugi T, Katagiri K. J Antibiot. 1975; 28:602. [PubMed: 1171848]

12b. Koyama K, Natori S, Iitaka Y. Chem Pharm Bull. 1987; 35:4049.

13a. Gill M. Nat Prod Rep. 2003; 20:615. [PubMed: 14700203]

13b. Isaka M, Kittakoop P, Kirtikara K, Hywel-Jones NL, Thebtaranonth Y. Acc Chem Res. 2005; 38:813. [PubMed: 16231877]

13c. Sperry J, Bachu P, Brimble MA. Nat Prod Rep. 2008; 25:376. [PubMed: 18389142]

14a. Bringmann G, Gulder T, Gulder TAM, Breuning M. Chem Rev. 2011; 111:563. [PubMed: 20939606]

14b. Kozlowski MC, Morgan BJ, Linton EC. Chem Soc Rev. 2009; 38:3193. [PubMed: 19847351]

15. Park YS, Grove CI, González-López M, Urgaonkar S, Fettinger JC, Shaw JT. Angew Chem Int Ed. 2011; 50:3730.

16. Bode SE, Drochner D, Mueller M. Angew Chem Int Ed. 2007; 46:5916.

17. Romaine IM, Hempel JE, Shanmugam G, Hori H, Igarashi Y, Polavarapu PL, Sulikowski GA. Org Lett. 2011; 13:4538. [PubMed: 21812391]

18. Coleman RS, Grant EB. J Am Chem Soc. 1995; 117:10889.

19. Kozlowski MC, Dugan EC, DiVirgilio ES, Maksimenka K, Bringmann G. Adv Synth Catal. 2007; 349:583.

20. Volkmann RA, Kelbaugh PR, Nason DM, Jasys VJ. J Org Chem. 1992; 57:4352.

21. Shen R, Inoue T, Forgac M, Porco JA. J Org Chem. 2005; 70:3686. [PubMed: 15845008]

22. Murata T, Sano M, Takamura H, Kadota I, Uemura D. J Org Chem. 2009; 74:4797. [PubMed: 19480417]

23. Bolla ML, Patterson B, Rychnovsky SD. J Am Chem Soc. 2005; 127:16044. [PubMed: 16287289]

24. Dalgard JE, Rychnovsky SD. Org Lett. 2005; 7:1589. [PubMed: 15816759]

25a. Evans GE, Leeper FJ, Murphy JA, Staunton J. J Chem Soc, Chem Commun. 1979:205.

25b. Dodd JH, Weinreb SM. Tetrahedron Lett. 1979; 20:3593.

26. Tan NPH, Donner CD. Tetrahedron. 2009; 65:4007.

27. Ferguson ML, O’Leary DJ, Grubbs RH. Org Synth. 2003; 80:85.

28. Crystallographic data for compound 9 have been submitted to Cambridge Crystallographic Database and assigned deposition number CCDC 858638.

29. Brockway AJ, Gonzalez-Lopez M, Fettinger JC, Shaw JT. J Org Chem. 2011; 76:3515. [PubMed: 21446670]

30. Miyake H, Tsumura T, Sasaki M. Tetrahedron Lett. 2004; 45:7213.

31. Han JH, Kwon YE, Sohn J-H, Ryu DH. Tetrahedron. 2010; 66:1673.

Synthesis (Stuttg). Author manuscript; available in PMC 2012 October 01. 
32. Guo Q-X, Wu Z-J, Luo Z-B, Liu Q-Z, Ye J-L, Luo S-W, Cun L-F, Gong L-Z. J Am Chem Soc. 2007; 129:13927. [PubMed: 17956093]

33. Armarego, WLF.; Chai, C. Purification of Laboratory Chemicals. 5. Butterworth Heinemann; Oxford: 2003. p. 608 


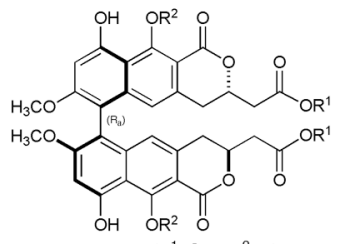

1, viriditoxin, $\left(\mathrm{R}^{1}=\mathrm{CH}_{3}, \mathrm{R}^{2}=\mathrm{H}\right)$

2, asteromine, $\left(\mathrm{R}^{1}=\mathrm{H}, \mathrm{R}^{2}=\mathrm{CH}_{3}\right)$
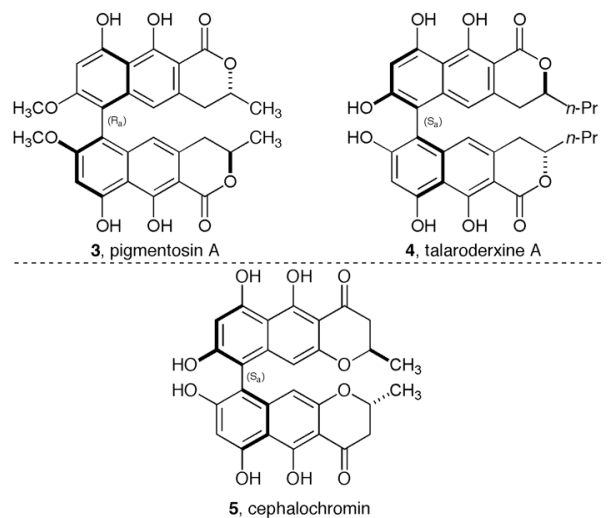

5. cephalochromin

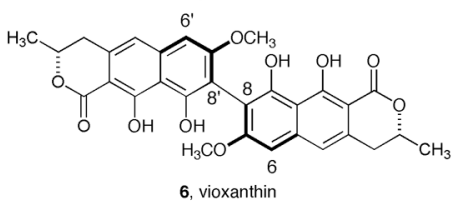

Figure 1. 


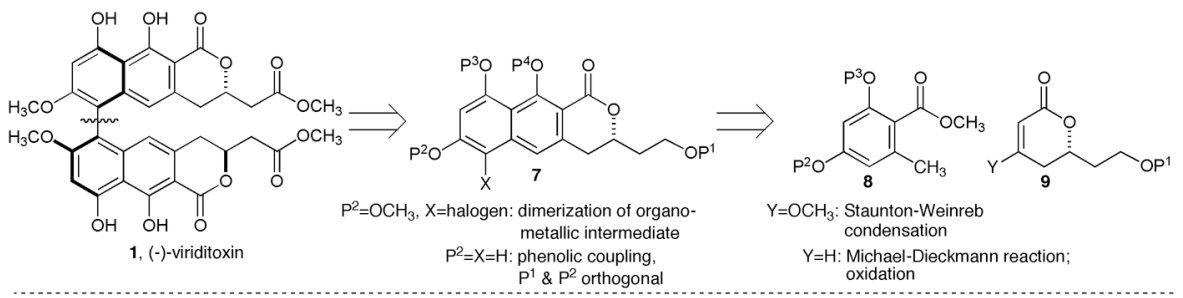

First Generation

- problematic deprotection of TIPS ( $\left.P^{\prime}\right)$

- large-scale tin-based allylayion

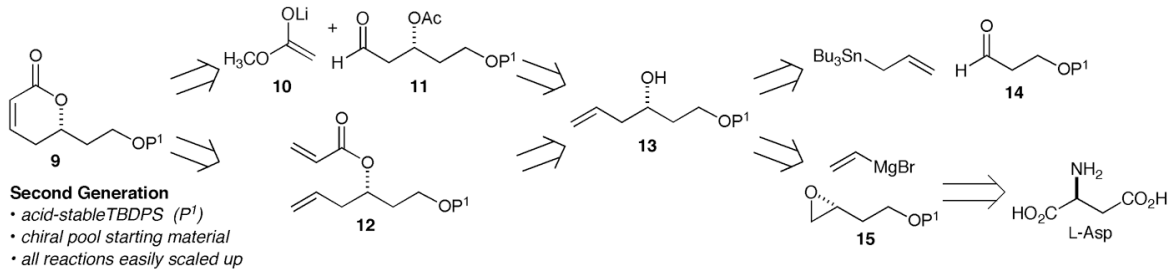

Scheme 1.

Synthesis (Stuttg). Author manuscript; available in PMC 2012 October 01. 
A $\mathrm{Bu}_{3} \mathrm{Sn} \sim$

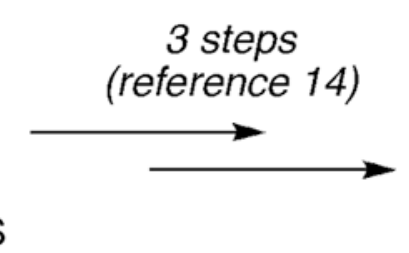

14 (two steps from propylene glycol)<smiles>O=C1C=CC[C@@H](CC[OH+][SH2])O1</smiles>

$9 a, 38 \%$ overall yield (5 steps)

B

1) $\mathrm{NaNO}_{2}, \mathrm{KBr}$,<smiles>NC(CC(=O)O)C(=O)O</smiles>
$\mathrm{H}_{2} \mathrm{SO}_{4} ; 82 \%$

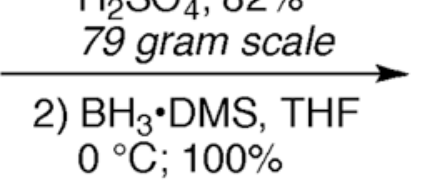<smiles>C=CC[C@H](O)CC[OH+]</smiles>

13a, $\mathrm{P}^{1}=$ TIPS; $57 \%$

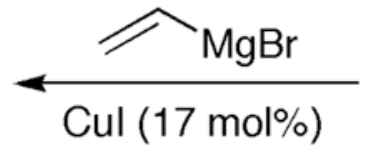<smiles>[O]CCC1CO1</smiles>
13b, $\mathrm{P}^{1}=$ TBDPS; $85 \%$

15a, $\mathrm{P}^{1}=$ TIPS; $87 \%$ 15b, $\mathrm{P}^{1}=$ TBDPS; $80 \%$<smiles>OCCC(Br)CO</smiles>
16<smiles>CCN(C)C=CC(=O)Cl</smiles><smiles>C=CC[C@@H](CC[Po+2])OC(=O)C=C</smiles>

12a, $P^{1}=$ TIPS; $67 \%$

12b, $\mathrm{P}^{1}=$ TBDPS; $85 \%$

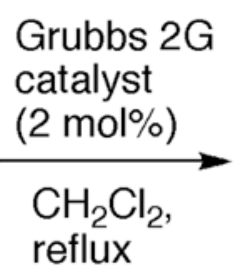
reflux<smiles>O=C1C=CC[C@@H](CCO[PbH2])O1</smiles>

9a, $P^{1}=$ TIPS; $97 \%$

9b, $\mathrm{P}^{1}=$ TBDPS; $85 \%$ $26 \%$ (9a) \& 49\% (9b) overall yields (6 steps)

Scheme 2. 
<smiles>CCOc1cc(OC)[12c]c(C)c1C(=O)OC</smiles>

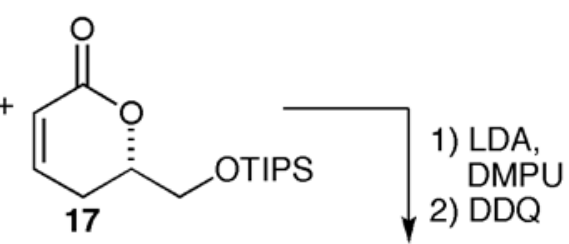

pretreatment
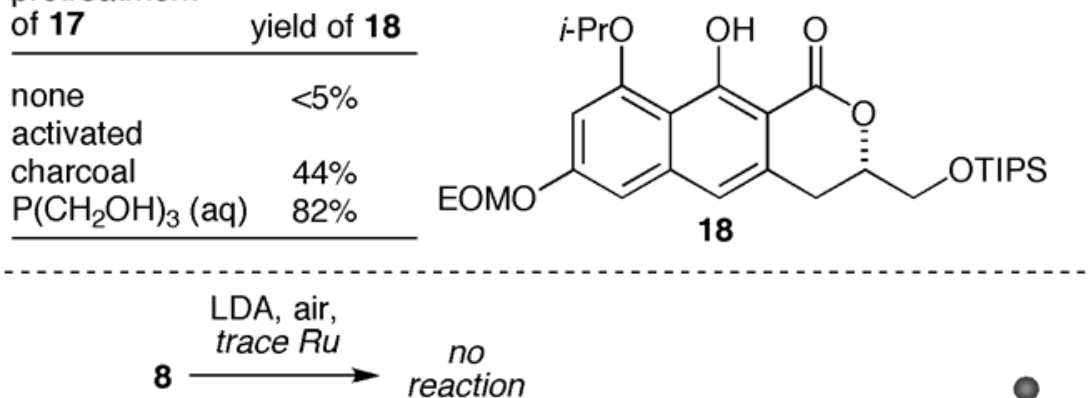
$\downarrow$ LDA, 17

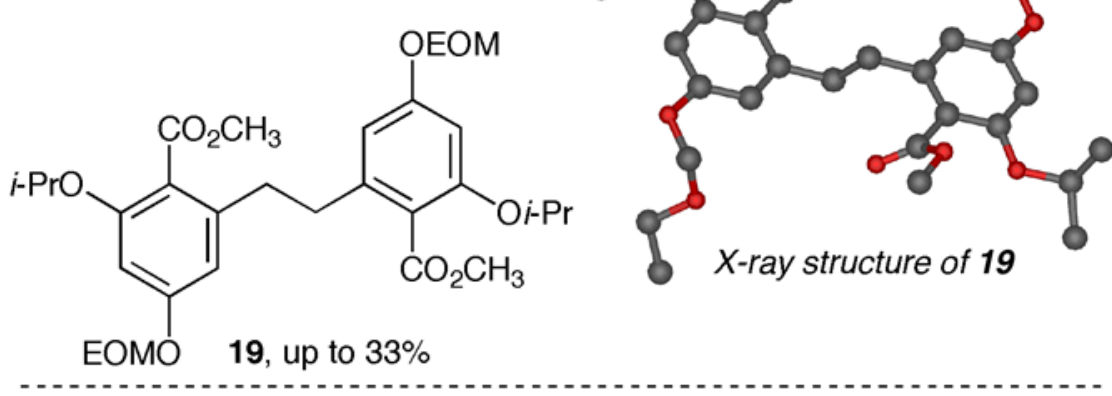<smiles>O=C1C=CC[C@@H](CC[OH2+])O1</smiles>
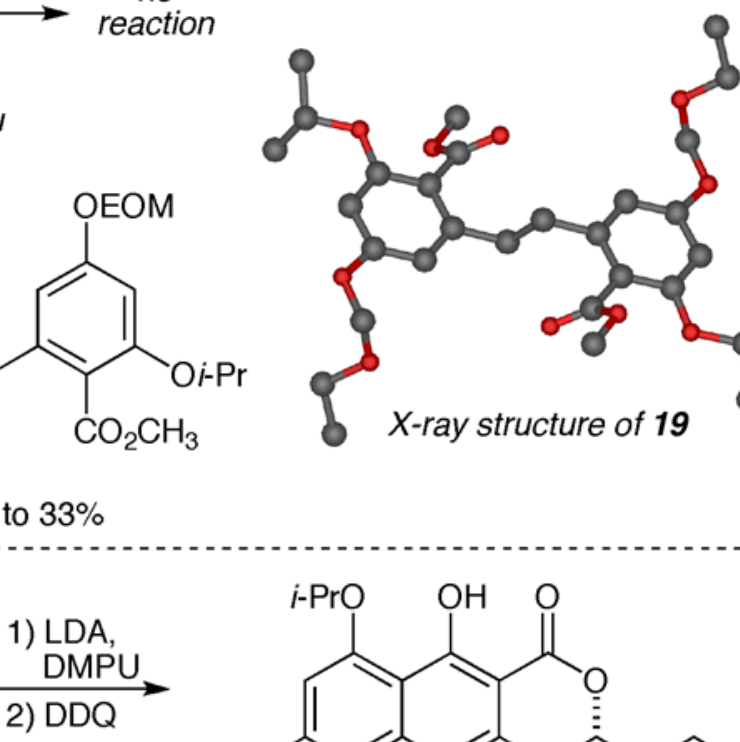

Scheme 3. 


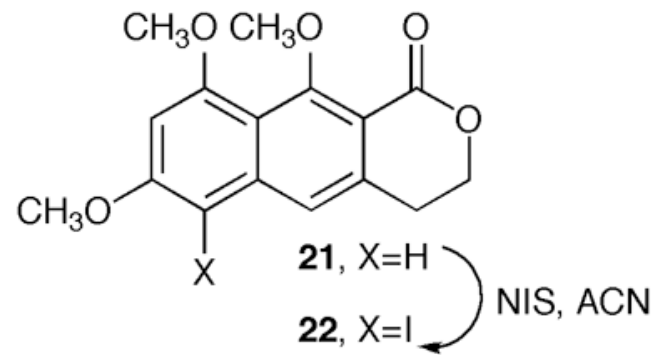

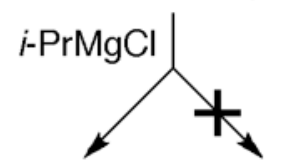

\section{$\mathrm{R}_{3} \mathrm{SnX}$ or}

$\mathrm{B}(\mathrm{OR})_{3}$<smiles>[X]c1c(OC)cc(O)c2c(CCC)c3c(cc12)CCOC3=O</smiles><smiles>[X]c1c(OC)cc(OC)c2c(O)c3c(cc12)CCOC3=O</smiles>

24, $X=H$ \& 25, $X=I, 50: 50$ not observed

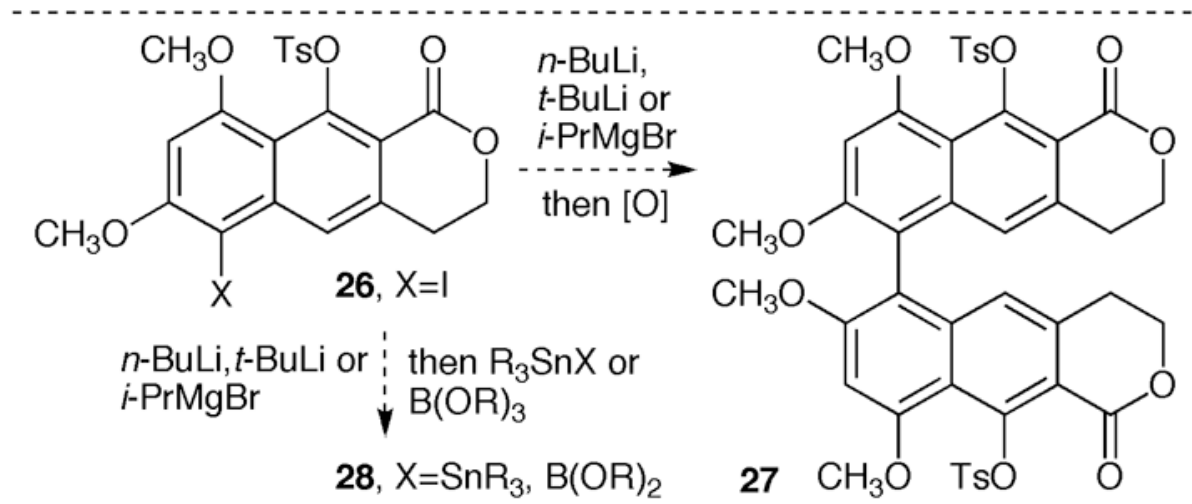

Scheme 4. 
first generation:

variable yields,

difficult to scale up<smiles>COc1cc(O)cc2cc3c(c(O)c12)C(=O)O[C@H](CC[OH+])C3</smiles>
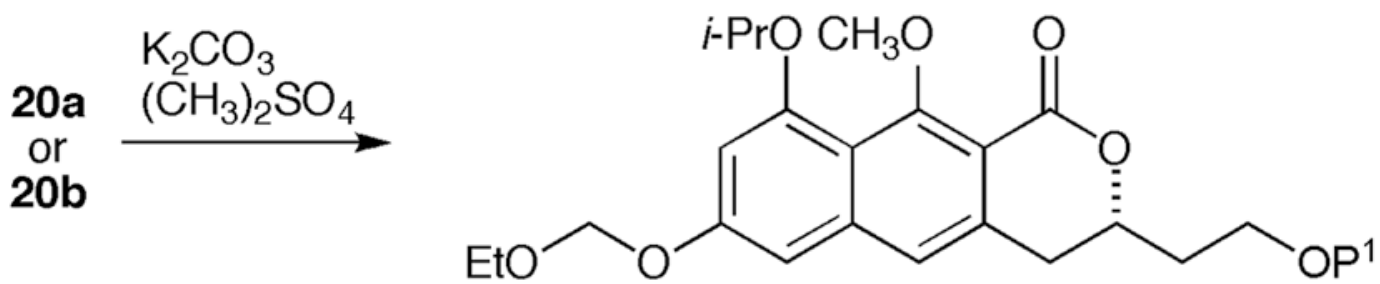

7a, $\mathrm{P}^{1}=$ TIPS, $72 \%$

7b, $\mathrm{P}^{1}=$ TBDPS, $75 \%$ $\mathrm{P}^{1}=$ TBDPPS $\mid \begin{aligned} & \mathrm{ZnBr}_{2}, n-\mathrm{PrSH} \\ & \mathrm{CH}_{2} \mathrm{Cl}_{2}, \mathrm{rt}\end{aligned}$

second generation: consistent yields, easily scaled up<smiles>COc1cc(O)cc2cc3c(c(O)c12)C(=O)O[C@H](CC[OH+][SbH2])C3</smiles>

Scheme 5. 
A
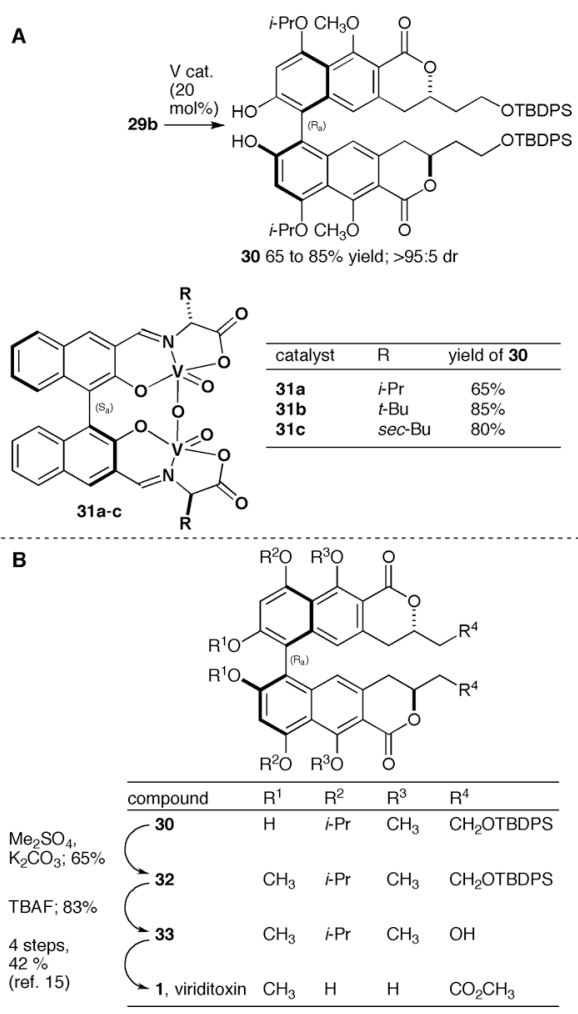

Scheme 6.

Synthesis (Stuttg). Author manuscript; available in PMC 2012 October 01. 